Kalem Eğitim ve İnsan Bilimleri Dergisi 2018, 8(1), 187-214, doi: 10.23863/kalem.2018.100

Makale Gönderim Tarihi:14.02.2017

Makale Kabul Tarihi:19.05.2017

\title{
Okul Psikolojik Danışmanlarının Danışma Sürecinde Sessizliğin Kullanımına İlişkin Görüşleri ve Deneyimleri
}

\author{
Doç. Dr. Tahsin İLHAN \\ Gaziosmanpaşa Üniversitesi, Eğitim Fakültesi, Eğitim Bilimleri Bölümü, Tokat / Türkiye, \\ tahsinilhan73@gmail.com, ORCID: 0000-0002-5007-5022 \\ Dr. Öğr. Üyesi Yusuf SARIKAYA* \\ Gaziosmanpaşa Üniversitesi, Eğitim Fakültesi, Eğitim Bilimleri Bölümü, Tokat / Türkiye, \\ yusufsarikaya@gmail.com, ORCID: 0000-0003-3057-3718
}

\section{$\ddot{O} z$}

Bu çalışmanın amacı psikolojik danışmanların psikolojik danışma sürecinde sessizliğin kullanımına ilişkin görüş ve deneyimlerini ortaya koymaktır. Araştırma 14 psikolojik danışmanla gerçekleştirilmiştir. Araştırma verileri yarı yapılandırılmış görüşme tekniği ile elde edilmiştir. Görüşmelerin analizi sonucunda danışmanların sessizliğin danışma sürecine olumlu katkılar sağladığını düşündükleri ortaya çıkmıştır. Psikolojik danışmanlara göre sessizlik danışanın içgörü kazanmasına yardım etmekte, danışmana da süreçle ilgili düşünme firsatı vermektedir. Danışmanların yarısı sessizliğin kullanımını bir teknik olarak görmekten ziyade, süreç içerisinde doğal olarak ortaya çıan bir durum olarak görmektedirler. Psikolojik danışmanların çoğunluğu sessizliğin danışma sürecinin ilk merhalelerinde nadiren meydana geldiğini, danışan-psikolojik danışman iletişimi kuvvetlendikçe daha fazla ortaya çıktı̆̆ını ifade etmektedirler. Psikolojik danışmanlar sessizlik anlarında daha çok danışma süreci ile ilgili şeyleri

* Sorumlu Yazar. Tel: +90 $3562521616 / 3646$

(C) 2018 Kalem Eğitim ve Sağlık Hizmetleri Vakfı. Bütün Hakları Saklıdır.

ISSN: $2146-5606$ 
düşünürken çoğunluğu bu anlarda yaşadıkları duyguların farkında değildirler. Psikolojik danışmanlar üniversite eğitimleri sırasında sessizliğin kullanımına ilişkin bir eğitim almadıklarını ifade etmekte ve tecrübe kazandıkça sessizliğin yönetilmesi konusunda daha fazla ustalaştıklarını ifade etmektedirler. Görüşmelerin sonuçları ilgili alanyazın kapsamında tartışılmıştır. Ayrıca psikolojik danışmanların eğitimi ve bu konuda yapılacak diğer araştırmalar konusunda öneriler sunulmuştur.

Anahtar Kelimeler: Sessizlik; Psikolojik danışman; Psikolojik danışmanlık becerileri; Mikro beceriler.

\title{
School Counselors' Views and Experiences on Uses of Silence in Counseling Process
}

\begin{abstract}
Aim of this study was to investigate counselors' views and experiences on uses of silence in counseling process. The study was carried out with 14 counselors. Data were obtained by semi-structured interview technique. Results showed that participants largely thought silence had positive contributions on counseling process. According to participants silence gave time for the clients gained insight and gave opportunity to think for counseling process for the counselors. Most of the participants agreed that silence was a situation that aroused spontaneously rather than a technique in the process. A majority of participants thought that silence rarely occurred in initial stages of counseling process, it mostly happened when a therapeutic relationship between counselor and client became stronger. Also the results implied that counselors were not aware of their feeling and emotions during silence, they mostly used the silence to look over the counseling process. A majority of participants reported that they did not receive any training on uses silence in counseling sessions. The participants also expressed that they got more competency when they got more experiences. The results of the analysis of the interviews were discussed with the relevant literature. Additionally, suggestions for counselor education and future researches were made.
\end{abstract} Keywords: Silence; School counselor; Counseling competencies; Counseling micro skills. 


\section{Extended Summary}

\section{Purpose}

Silence experienced in counseling sessions, similar to the one in our daily life, is a compelling phenomenon especially for novice counselors (Hill, Thompson and Ladany, 2003; Lane, Koetting and Bishop, 2002; Levitt, 2001a, 2001b; Sharpley, Munro and Elly, 2005). However, when silence is used seasonably could turn into an intervention method which could increase therapeutic alliance between counselor-client (Ladany, Hill, Thompson and O'Brien, 2004; Sharpley, 1997; Sharpley, Munro and Elly, 2005) and could regulate therapeutic process (Frankel, Levitt, Murray, Greenberg and Angus, 2006).

Silence was interpreted as a resistance (Arlow, 1961; Freud, 1912; Hadda, 1991), retreat (Shafii, 1973; Stringer, Levitt, Berman and Mathews, 2010), ego-defense (Sabbadini, 1986) and reaction of transference/countertransference (Ronningstam, 2006) by conventional psycho-analysis approach. Similar views that silence is an indicator of resistance shared by person-centered and Gestalt approaches (Denham-Vaughan and Edmond, 2010; Otani, 1989). On the contrary to these views, numbers of researchers and theoreticians following neo-psycho-analytic approach (Bravesmith, 2012; Gale and Sanchez, 2005; Gans and Counselman, 1999; Levitt, 2002; Meissner, 2000; Sabbadini, 1991; Urlic, 2010) emphasized that silence is a valuable communication way which needs to be comprehend instead of an adverse circumstance that needs to be cope with.

According to the literature, it is possible to state that silence represents more than halts in speaking (Sabbadini, 1991), and that they are multi-dimensional (Levitt, 2001a, 2001b), and that it has positive influence on therapeutic alliance and counseling outputs positively when it is used effectively (Sharpley, Munro and Elly, 2005). Additionally, limited numbers of the empirical research cannot reveal the function of silence in the counseling process (Ladany et al., 2004). Therefore, there is need for more qualitative studies which could gather information deeply, which could reflect experiences and insights of counselors.

Although total number of studies on psychological counselor skills and competencies has been increased (i.e., Meydan, 2015; Yaka, 2005; Yam and İlhan, 2016), studies on micro-skills such as silence have remained limited. Especially in Turkey, a lack of research on counselors' perception of silence 
is considered as a significant deficiency which needs to be taken into consideration in counseling education. Therefore, the present study aims to investigate into how psychological counselors perceive silence and how they manage silence during counseling sessions.

\section{Method}

The study was conducted on 14 school counselors. Data in this study were collected by a means of interviews. To that end, a semi-structured interview form consisted of 12 open-ended questions was prepared based on the previous studies on the subject. After three preliminary interviews, the final version was formed. Interviews were transcribed verbatim. Data was analyzed by descriptive analysis method (Yıldırım and Şimşek, 2000). Analyzing data, a code assigned to participants (from K1 to K14). Records were analyzed by both researchers separately. Thus, totally 11 sub-themes were determined under the five major themes.

\section{Result}

Core themes determined within the study were titled as education on silence, silence process, tolerance to silence, usage of silence and contributions of silence. Education on silence theme includes education of counselors and train to clients' sub-themes. Concerning these themes findings showed that almost none of respondents received a specific course during their undergraduate and graduate education. However, majority of respondents $(\mathrm{n}=11$; 78.57\%) reported that silence was studied in some theoretical and applied courses superficially. Moreover, all of respondents stated that they do not train their counselees about silence. Under the silence process theme, the two subthemes were determined as management of silence and response to silence. According to findings related with these sub-themes, it could be understood that respondents did not have a general form for management of silence. Management of silence varies with respect to client and the reason of silence. The respondents stated that they were trying to establish empathy with their clients during silence; thinking about further processes of counseling; and trying to maintain eye-contact with their clients. Tolerance to silence theme is composed of sub-themes of duration of silence and breaking of silence. Many of the participants $(n=9 ; 64.29 \%)$ stated that the length of silence was almost 1 5 minutes. This time is less than 1 minute for some participants $(n=3 ; 21.43 \%)$ whereas it is more than 5 minutes for others $(n=2 ; 14.29 \%)$. Nearly half of the 
participants $(n=6 ; 42.86 \%)$ stated that they broke the silence generally. However, according to other participants $(n=5 ; 35.71 \%)$, the clients broke the silence as well.

Under the silence usage themes, two sub-themes of usage of silence during counseling sessions and source of silence were determined. The majority of respondents who work at high schools $(n=7 ; 50 \%)$ stated that silence was not used frequently at the beginning of counseling process Silence was used more frequently after the counselor-counselee relationship was developed. Two respondents who worked at primary school with younger children stated that silence occurred more frequently at the beginning stages of counseling. Moreover, majority of respondents $(n=10 ; 71.43 \%)$ were of the opinion that counselor was the primary source of silence although this situation depends on clients or nature of their problems. Finally, contribution of silence theme is consisted of three sub-themes of contribution to counselor, contribution to counselee and contribution to counseling process. The respondents stated that in silence periods, they gained opportunity to rest their mind, revise the process and convey more messages to counselees with their body language. Regarding contribution of silence to counselee, following issues were reported; confrontation with client himself/herself, beginning to take responsibility, insight development, relaxing, giving opportunity to self-disclosure. The respondents considered silence as evidence of effective counseling process.

\section{Discussion and Conclusion}

On the basis of the findings of this study, it seemed possible to claim that silence would mean more than the breaks encountered during speaking periods. In the meantime, the findings revealed that silence exhibits functions such as focusing, increasing awareness and resting mind rather than resistance, and retreat or ego defense. In other words, the results of the study confirmed that obstructive, productive and neutral silence periods classified by Levitt (1998, 2001a) were experienced during counseling process. As far as is known, this study is the first research to investigate experiences of counselors about silence in Turkey but with some limitations. Firstly, this study included only counselors' views about silence. In order to obtain deeper information, it would be useful to investigate views and experiences of counselors and counselees simultaneously. Moreover, silence moments and the party who used silence more were tried to be determined based on perceptions only. In order 
to acquire more accurate result, visual-auditory records can be investigated. In this qualitative study, limited numbers of counselors were interviewed. Therefore, quantitative studies can conduct to reach more participants for increase generalizability findings. Finally, as the findings suggested, respondents were not educated on silence; and they developed their skills with the help of their experiences. Therefore, not only basic counseling skills but also micro skills such as silence could be improved in counselor training.

\section{Giriş}

Günlük hayattaki konuşmalarda olduğu gibi psikolojik danışma oturumlarında da yaşanan sessizlik, özellikle deneyimsiz psikolojik danışmanlar için zorlayıcı bir olgudur (Hill, Thompson ve Ladany, 2003; Lane, Koetting ve Bishop, 2002; Levitt, 2001a, 2001b; Sharpley, Munro ve Elly, 2005). Bununla birlikte, sessizlik yerinde ve zamanında kullanıldığında terapötik süreci düzenleyen (Frankel, Levitt, Greenberg ve Angus, 2006) danışman-danışan arasındaki çalışma işbirliğini ve kaynaşmayı artıran (Ladany, Hill, Thompson ve O'Brien, 2004; Sharpley, 1997; Sharpley, Munro ve Elly, 2005) bir müdahale yöntemine dönüşebilmektedir.

Sessizlik, geleneksel psikanaliz yaklaşımı tarafından bir direnç (Arlow, 1961; Freud, 1912; Hadda, 1991), geri çekilme (Shafii, 1973; Stringer, Levitt, Berman ve Mathews, 2010), ego savunması (Sabbadini, 1986) ve aktarım/karşıt aktarım (Ronningstam, 2006) tepkisi olarak yorumlanmıştır. Sessizliğin bir direnç işareti olduğu yönündeki benzer görüşler danışan merkezli yaklaşım ve gestalt yaklaşımı tarafından da paylaşılmış, sessizliği; süreci zorlaştırıcı bir faktör olarak değerlendirmişlerdir (Denham-Vaughan ve Edmond, 2010; Otani, 1989). Bu görüşlerin aksine başta neo-psikanalitik yaklaşımı takip eden birçok kuramcı ve araştırmacı (Bravesmith, 2012; Gale ve Sanchez, 2005; Gans ve Counselman, 1999; Levitt, 2002; Meissner, 2000; Sabbadini, 1991; Urlic, 2010) sessizliğin başa çıkılması gereken olumsuz bir durum olmaktan daha çok, anlaşılması gereken değerli bir iletişim biçimi olduğuna vurgu yapmışlardır. Sabbadini (1991) sessizliğin danışma sürecinde iletişimi tamamlayıcı olduğunu ve dirençten daha fazla şey ifade ettiğini; terapistleri ise sessizliği, danışanların içsel dünyalarını daha iyi incelemeye yardımcı olmak için kullanmaları gerektiğini belirmiştir.

Sessizliğin terapideki rolüne yönelik değişen paradigma ve buna bağl1 giderek artan sayıdaki çalışmalarla farklı türde ve işlevde sessizliğin olduğu ortaya konulmuştur (Frankel ve ark., 2006; Levitt, 1998, 2001a; Stringer ve 
ark., 2010). Örneğin, Levitt (1998, 2001a) gömülü teoriye dayalı olarak yapmış olduğu bir dizi araştırmada kendi içinde yedi alt kategorilerden oluşan zorlayıc1/engelleyici, üretici ve nötr olarak adlandırdığı üç sessizlik türü belirlemiştir. Engelleyici sessizlik, daha çok konuyu geçiştirme, tedirginlik, kaygı ve duyguları gizleme gibi tepkileri içerirken; üretici sessizlik, düşünceleri toparlama, duygulara inme ve ifade etme, farkındalık ve içgörü geliştirmeyle ilgilidir. Nötr sessizlik ise hafızayı kullanma, geçmiş olayları hatırlama, konuyu sonlandırma ve yeni bir konuya geçme gibi tepkilerle ilgilidir. Levitt (2001b) başka bir çalışmasında danışma sürecinde yaşanan sessizliğin sadece \%22'sinin engelleyici sessizlik olduğunu bulmuştur. Bu bulgu Sabbadini'nin (1991) belirtiği gibi tüm sessizliklerin geleneksel psikanalitik yaklaşımın öne sürdüğü direnç ya da gerileme işareti olarak yorumlanamayacağ düşüncesini desteklemiştir.

Alanyazındaki çalışmalar, danışan ve psikolojik danışman tarafından etkili bir şekilde kullanılan sessizliğin terapötik ittifakı artırdığını (Sharpley, 1997; Sharpley, Munro ve Elly, 2005) ve olumlu danışma çıktılarıyla (Frankel ve ark., 2006; Stringer ve ark., 2010) ilişkili olduğunu ortaya koymuştur. Örneğin, Sharpley (1997) ile Sharpley, Munro ve Elly'nin (2005) danışman adaylarının görüşme kayıtlarını inceledikleri çalışmalarında danışanlar tarafından algılanan yüksek düzeyde kaynaşmanın (rapport) olduğu anlarında sessizliğin daha fazla yaşandığı bulunmuştur. Benzer bulgulara Ladany ve diğerlerinin (2004) yaptığı çalışmada da ulaşılmıştır. Lambert' in (1992) ortak faktörler modeline göre danışma çıktılarının \%30'unun terapötik ittifak ile açıklandığı dikkate alındığında, ittifakı artıran sessizliğin etkili kullanımın ne kadar önemli olduğu daha iyi anlaşılabilir.

Sessizliğin türleri ve işlevlerinin yanında danışan ve psikolojik danışman tarafından hangi anlarda ve gerekçelerle kullanıldığına yönelik yapılan çalışmalar bu konuda önemli bulgular sunmaktadır (Barber, 2009; Endrass, Rehm, Andre ve Nakano, 2008; Ladany ve ark., 2004; Tindall ve Robinson, 1947). Bu konuda bilinen ilk çalışmalardan birisi Tindall ve Robinson (1947) tarafından yapılmıştır. Araştırmacılar 61 danışma kaydını analiz etmişleridir. Bulgulara göre danışanlar sessizliği sırasıyla, soruya cevap vermek için düşünmek, yeni bir düşünceye geçmek ve direnç gösterisi olarak kullanırken; psikolojik danışmanlar, sessizliği en fazla konuşma öncesi düşüncelerini toparlamak, ikinci olarak da danışma sürecine danışanın daha fazla katkı sağlamasını teşvik etmek için kullanmışlardır. Bir vak’a analizi çalışmasında ise 
(Ronningstam, 2006) danışanın sessizliği, benliğini koruma ve aktarım amacıyla; danışmanın ise tepkilerini kontrol etmek ve empati geliştirmek için kullandığ belirtilmiştir.

Alanyazında sessizlik konusunda danışma kayıtları incelenerek yapılan çalışmaların yanında sınırlı sayıda da olsa psikolojik danışmanların görüşlerinin alındığı çalışmalar yapılmaktadır. Ladany ve arkadaşları (2004) tarafindan gerçekleştirilen bir çalışmada, 12 psikolojik danışmanın sessizliği nasıl kullandıklarıyla ilgili deneyimleri incelenmiştir. Bulgulara göre psikolojik danışmanların sessizliği empatiyi iletmek, destek sunmak, danışanı konuşmaya ve sorumluluk almaya teşvik etmek için tercih ettikleri; psikotik, bağımlı, kaygıl1, paranoid ve şüpheci olan danışanlarda sessizliği kullanmadıkları belirtilmiştir. Ayrıca, psikolojik danışmanların başlangıç oturumlarında sessizliği daha az tercih ettikleri belirtilirken, sessizlik etkili kullanıldığında terapötik işbirliğinin kalitesinin arttığı ifade edilmiştir. Son olarak, katılımcıların büyük bir çoğunluğunun danışanlarını sessizlik konusunda eğittikleri ve her bir oturumda toplam sessizlik süresinin ortalama iki dakika olduğu rapor edilmiştir. Hill, Thompson ve Ladany (2003) danışmanların sessizlikle ilgili deneyimlerini incelemek için Ladany ve arkadaşlarının (2004) nitel çalışmasını genişleterek anket yolu ile daha fazla katılımcıya ulaşmışlardır. Bulgular, psikolojik danışmanların sessizliği empati kurma, duyguları ifade etmeyi kolaylaştırma, danışanı sorumluluk alma konusunda cesaretlendirme, düşüncelere odaklanmasını kolaylaştırma ve akışı bozmamak için tercih ettiklerini ortaya koymuştur. Ayrıca psikolojik danışmanların, sessizliği aktif problem çözen danışanlarda daha fazla, huzursuz danışanlarda daha az kullanmayı tercih ettikleri sonucuna ulaşı1mıştır.

Alanyazındaki çalışmalar genel olarak değerlendirildiğinde, sessizliğin konuşmalar arasındaki duraklamalardan daha çok şey ifade ettiği (Sabbadini, 1991), çok boyutlu olduğu (Levitt, 2001a, 2001b), etkili kullanıldığında terapötik ittifakı ve danışma çıktılarını olumlu yönde etkilediği (Sharpley, Munro ve Elly, 2005) söylenebilir. Bununla birlikte, ampirik araştırmaların sınırlı sayıda olması ve daha çok danışma kayıtları üzerinden, çeşitli kodlama yöntemleriyle sessizliğin anlaşılmaya çalışması ulaşılan bilgileri de sınırlı hale getirmektedir (Ladany ve ark., 2004). Bu nedenle derinlemesine bilgi toplanabilecek, psikolojik danışmanların deneyimlerini ve içgörülerini yansıtabilecek nitel desende daha fazla araştırmaya ihtiyaç duyulmaktadır. 
Türkiye'de psikolojik danışman becerilerine ve yeterliklerine ilişkin araştırmalar artış göstermesine karşın (ör., Meydan, 2015; Yaka, 2005; Yam ve İlhan, 2016) sessizlik gibi mikro becerilere yönelik çalışmalar sınırlı sayıda kalmaktadır. Yıldırım'ın (2012) çalışmasında, grup yaşantısı geçiren üyelerin suskunluk nedenleri incelenmiş ve elde edilen bulgular üyelerin sessizliği daha çok direnç olarak kullandıklarını göstermiştir. Bu çalışma, grup sürecindeki üyelerin sessizliği neden kullandıkları konusunda değerli bilgiler sunmakla birlikte, psikolojik danışmanların sessizliği hangi durumlarda kullandıkları, sessizliği nasıl yönettikleri ve sessizliğin danışma sürecine ne gibi etkilerinin olduğu gibi sorulara cevap verememektedir. Özellikle Türkiye'de, psikolojik danışmanların sessizlik konusundaki algılarına yönelik bir çalışmaya rastlanmaması ve kültürden oldukça etkilenen sessizliğin (Endrass ve ark., 2008; Ronningstam, 2006) Türkiye'deki psikolojik danışmanlar tarafindan nasıl algılandığının bilinmemesi, psikolojik danışmanlık eğitiminde dikkate alınması gereken bir eksiklik olarak karşımıza çıkmaktadır. Bu nedenle, bu araştırmada psikolojik danışmanların sessizliği nasıl algıladıklarına ve danışmada nasıl yönettiklerine dair görüşlerinin incelenmesi amaçlanmıştır. Ayrıca bu çalışmada sessizlik sürecinde psikolojik danışmanların neler yaptıkları, kendilerine ve danışanlara ne gibi katkı sağladığı araştırılmaya değer bulunmuştur.

\section{Yöntem}

Nitel araştırmalar incelenen olgu ya da olay hakkında sosyal gerçekliğe dayalı, ayrıntılı ve derinlemesine bilgi sunması açısından önemli görülmektedir (Berg, 2009; Creswell, 2013; Yıldırım, 1999). Psikolojik danışmanların, danışma sürecindeki sessizliğe ilişkin bakış açılarını ve deneyimlerini ayrıntılı olarak ortaya çıkarmayı amaçlayan bu araştırma nitel olarak tasarlanmış betimsel bir çalışmadır. Veriler yarı yapılandırılmış görüşme tekniği kullanılarak toplanmıştır. Katılımcılar, veri toplama süreci ve verilerin analizi hakkındaki bilgiler aşağıda açıklanmıştır.

\section{Katılımcılar}

Araştırma Orta Karadeniz Bölgesinin bir ilinde çalışan okul psikolojik danışmanlarıyla yürütülmüştür. Araştırma verileri 2012 yılı içerisinde toplanmış ve örneklem seçiminde amaçlı örnekleme yöntemi kullanılmıştır (Johnson ve Christensen, 2014). Psikolojik danışmanlara e-posta ya da telefon yoluyla ulaşılmış, araştırmadan kısaca bahsedilmiş ve yüz yüze yapılacak görüşmelere 
katılmayı isteyip istemedikleri sorulmuştur. Ayrıca çalıştıkları kurumlarda düzenli ve sonuca ulaşan bir şekilde psikolojik danışma yapıp yapmadıkları da sorulmuştur. E-posta ya da telefon yoluyla ulaşılan 73 psikolojik danışmandan çalışmaya katılmaya gönüllü olan ve düzenli bir şekilde psikolojik danışma yaptığını ifade eden 14 kişi çalışma grubuna dâhil edilmiştir. Katılımcıların yaşları 24 ile 45 arasında değişmekteyken $(\bar{X}=31.78)$, görev süreleri ise beş ay ile 21 yıl arasında değişmektedir $(\overline{\mathrm{X}}=9.1)$. Tamamı psikolojik danışma ve rehberlik/eğitimde psikolojik hizmetler programından mezun olan katılımcılara ilişskin diğer bilgiler Tablo 1'de verilmiştir.

Tablo1. Katılımcılara İlişkin Bilgiler

\begin{tabular}{llcc}
\hline & & $\mathbf{n}$ & $\mathbf{\%}$ \\
\hline \multirow{2}{*}{ Cinsiyet } & Erkek & 6 & 42.86 \\
& Kadın & 8 & 57.14 \\
\hline \multirow{2}{*}{ Eğitim Durumu } & Lisans & 11 & 78.57 \\
& Yüksek Lisans & 3 & 21.43 \\
\hline \multirow{2}{*}{ Psikolojik } & Eklektik & 7 & 50.00 \\
Danışma & Danışandan Hız Alan & 5 & 35.72 \\
Yaklaşımı & Bilişsel-davranışçı & 1 & 7.14 \\
& Gestalt & 1 & 7.14 \\
\hline \multirow{3}{*}{ Görev Yeri } & İlkokul & 3 & 21.43 \\
& Ortaokul & 2 & 14.29 \\
& Lise & 8 & 57.14 \\
\hline Toplam & Rehberlik ve Araştırma Merkezi & 1 & 7.14 \\
\hline
\end{tabular}

\section{Verilerin Toplanması}

Veriler görüşme yöntemiyle toplanmıştır. $\mathrm{Bu}$ amaçla, konu ile ilgili daha önce yapılan çalışmalardan yola çıkarak hazırlanan ve 12 açık uçlu sorudan oluşan yarı yapılandırılmış görüşme formu hazırlanmıştır. Daha sonra psikolojik danışmanlık alanında doktora eğitimine sahip üç akademisyenden formu değerlendirmeleri istenmiştir. Sonraki merhalede taslak form ile üç ön uygulama yapılmış ve her bir uygulama sonrasında sorularda düzenlemelere gidilmiştir. Ayrıca görüşülen kişilerden mümkün olduğunda derinlemesine bilgi toplayabilmek amacıyla 12 soruya ek olarak alanyazında da önerildiği şekliyle çeşitli alternatif sorular, sondaj soruları (probing questions) ve tamamlayıcı sorular hazırlanmıştır (Patton, 2014; Yıldırım ve Şimşek, 2000). Hazırlanan bu sorular bir sonraki ön uygulamada denenmiş ve böylece üç ön 
uygulama sonucunda görüşme formuna son şekli verilmiştir. Görüşme formunda yer alan sorular şu şekildedir:

1. Psikolojik danışmada sessizliğin kullanılması ile ilgili bir eğitim aldınız mı? Aldıysanız nereden aldınız?

2. Sessizliği çoğunlukla danışma sürecinin hangi aşamalarında kullanırsınız? Hangi aşamalarda kullanmaktan kaçınırsınız?

3. Sessizliği kullanıp kullanmamanızı belirleyen ne tür faktörler var? Sessizliği kullanmaktan kaçındığınız durumlar var mı, bunlar nelerdir? Sessizliğin kullanılmasının zararlı olduğunu düşündüğünüz durumlar var mı? Bunlar neler?

4. Psikolojik danışman olarak siz hangi durumlarda sessiz kalırsınız? Sessiz kalma sebebiniz nedir?

5. Sessizliğin kaynağı daha çok kimdir? Danışan mı yoksa siz mi?

6. Danışma sırasında meydana gelen sessizlik anlarını nasıl yönetiyorsunuz?

7. Sessizlik anlarında neler düşünürsünüz?

8. Sessizlik anlarında hangi duyguyu yoğun olarak yaşarsınız?

9. Sessizlik anlarında neler yaparsınız?

10. Sessizliğe ne kadar tolerans gösterirsiniz? Belirli bir süreden bahsedebilir miyiz? Sessizliği genelde hangi taraf bozar? Hangi durumlarda sessizliği bozmak zorunda kalırsınız?

11.Danışanlarınıza sessizliği nasıl kullanacakları hakkında bilgi verir misiniz? Verirseniz bunu hangi aşamada yaparsınız?

12. Sessizliğin danışma sürecine nasıl bir katkı sağladığını düşünüyorsunuz?

Uygun saatler belirlendikten sonra, görüşmeciler katılımcıları çalıştıkları okul ve kurumlarda ziyaret etmişler ve görüşmeler de katılımcıların kendi ofislerinde gerçekleştirilmiştir. Görüşmelere başlamadan önce katılımcılarla çalışma işbirliğini destekleyici bir ilişki kurulmaya çalışılmış, çalışmanın amacına, gizlilik konularına değinilmiş daha sonra da bilgilendirilmiş onam formunu imzalamaları istenmiştir. 13 katılımcı ses kaydı alınmasını kabul ederken, bir katılımcı bunu kabul etmemiştir. Bu katılımcıyla gerçekleştirilen görüşmede, görüşmeci tarafından tutulan notlar kullanılarak analiz gerçekleştirilmiştir. Görüşmeler yaklaşı 11 ile 43 dakika arasında sürmüştür ( $\bar{X}=19$ dk., 12 sn.). Ön uygulama amacıyla gerçekleştirilen üç görüşme ikinci yazar tarafindan gerçekleştirilirken, asıl uygulamada gerçekleştirilen 14 görüşmenin 
8'i birinci yazar, 6'sı ikinci yazar tarafından gerçekleştirilmiştir. Görüşmelerin tamamlanması ön görüşmelerle birlikte yaklaşık 4 ay sürmüştür.

\section{Verilerin Analizi}

Verilerin analizinde betimsel analiz yöntemi kullanılmıştır. Bu analiz yöntemi nitel verilerin önceki araştırmalar ışığında oluşturulan bir çerçeveye oturtulmasına imkân vermektedir (Yıldırım ve Şimşek, 2000). Analiz sürecinde öncelikle her katılımcıya bir kod numarası verilmiş (K1-K14 arası) ve görüşme kayıtları ayrıntılı bir şekilde yazılı hâle getirilmiştir. Daha sonra bu kayıtlar her iki araştırmacı tarafından ayrı ayrı analiz edilerek tema ve alt temalara ilişkin kodlamalar yapılmıştır. Tema ve alt temaların oluşturulmasında tümevarımsal ve tümdengelimsel yöntemler birlikte kullanılmıştır. Tümevarımsal yöntemde toplanan verilerden temaların ortaya çıkarılması amaçlanırken, tümdengelimsel yöntemde ise önceden ortaya konulan bir modelden yola çıkılarak bunun test edilmesi söz konusudur (Yıldırım, 1999). Bu araştırmada kullanılan yarı yapılandırılmış görüşme formu, konu ile ilgili daha önce gerçekleştirilen çalışmalardan yola çıkılarak hazırlanmış ve böylece araştırma sonucu elde edilebilecek temalara yönelik kaba bir çerçeve sunmuştur. Ancak tema ve alt temalara son şeklinin verilmesinde araştırmacılar tarafından gerçekleştirilen kodlamalar dikkate alınmıştır.

Nitel veri setinin çözümlenmesi, kodlamaların yapılarak alt temalara ulaşılması her iki yazar tarafından ayrı ayrı gerçekleştirilmiştir. Kodlamalar sonucunda alt temalara ilişkin yazarlar arsında büyük oranda uzlaşma olduğu görülmüştür. Yazarlar arası tutarlık Miles ve Huberman'ın (1994) tarafindan önerilen uzlaşma yüzdesi formülüyle hesaplanmıştır [Uzlaşma yüzdesi = Görüş Birliği / (Görüş Birliği + Görüş Ayrılığı) x 100]. Böylece yazarlar arası tutarlık \%85 olarak bulunmuştur. Üzerinde uzlaşma olmadığı görülen iki alt tema tartışılarak alt temalara son şekli verilmiştir. Alt temalar yazarlar tarafından birlikte incelenerek temalar oluşturulmuştur. Böylece beş tema altında toplanan 11 alt tema belirlenmiştir.

\section{Geçerlik ve Güvenirlik}

Nitel araştırmalarda geçerlik ve güvenirlik kavramları yerine, bu kavramların her ikisini de kapsayan ve Türkçeye güvenirlik ya da güvenilmeye değerlik olarak çevrilebilecek 'trustworthiness' kavramı önerilmiştir (Lincoln ve Guba, 1985). Bu kavramla araştırmanın nitelik ve kalitesine vurgu yapılmakta, niteliği sağlamak için ise inanılırlık (credibility), yansızlık (neutrality), doğrulanabilirlik (confirmability), tutarlık (consistency), aktarılabilirlik 
(transferability) gibi şartlar öne sürülmektedir. (Davies ve Dodd, 2002; Golafshani, 2003; Lincoln ve Guba, 1985; Patton, 2014). Bu şartların sağlanmas1 için ise katılımcı teyidi, üçgenleme, uzman görüşü alma, araştırma aşamalarını ayrıntılı betimleme, sınırlılıkları tartışma, nitel veriyi destekleyen örnekler sunma, örneklem çeşitliliğini sağlama ve araştırmacının tarafsı kalması gibi yöntemler önerilmektedir (Krefting, 1991; Lincoln ve Guba, 1985; Yıldırım ve Şimşek, 2000).

Araştırma süreci, kullanılan yöntemler, katılımcıların özellikleri olabildiğince ayrıntılı anlatılarak doğrulanabilirlik artırılmaya çalışılmıştır. Ayrıca bulgular sunulurken alt temalarla ilgili katılımcıların kendi ifadelerinden örnekler verilmiştir. Araştırmanın inanılırlığı sağlamak için görüşme formu hazırlanırken uzman görüşü alınmış ve ön uygulamalar gerçekleştirilmiştir. Katılımcilarla uzun süreli etkileşim kurulmuş (prolonged engagement), yeterli güven oluşmadan görüşmeye başlanmamıştır. Ayrıca katılımcı teyidine başvurulmuş, her görüşme sonunda görüşme özetlenerek katılımcıların onayı alındığı gibi daha sonra araştırma bulguları e-posta yoluyla katılımcılarla paylaşılarak görüşleri de alınmıştır. Örneklem grubunda çeşitlemeye gidilerek, farklı okul türlerinden, çalışma süreleri birbirinden farklı katılımcılar katılımcı gruba dahil edilmiş ve böylece araştırma sonuçlarının aktarılabilirliği artırılmıştır. Tutarlık, araştırma verilerinin araştırmacılar tarafından ayrı ayrı analiz edilmesi ile sağlanmıştır. Ayrıca uzlaşma yüzdesi formülüyle hesaplanan yazarlar arası tutarlık da yeterli görülüştür (\%85). Yansızlığın sağlanması için araştırmacılar, görüşmelerin gerçekleştirilmesi başta olmak üzere tüm süreç boyunca tarafsız kalmaya özen göstermişlerdir. Bu süreçte Patton'ın (2014) da önerdiği şekliyle empatik yansız bir tavır takınılmıştır. Açık uçlu sorular kullanılmış, yönlendirmeci sorulardan kaçınılmıştır.

\section{Bulgular}

Gerçekleştirilen görüşmelerin incelenmesi sonucunda beş tema ve her temaya ait çeşitli alt temalar elde edilmiştir. Tespit edilen temalar sessizlikle ilgili eğitim, sessizlik süreci, sessizliğe tolerans, sessizliğin kullanımı ve sessizliğin katkıları olarak adlandırılmıştır. Tema ve alt temalar Tablo 2'de gösterilirken, bunlara ilişkin bulgular ise ayrı başlıklar halinde sunulmuştur. 
Tablo 2. Araştırma Sonucu Ortaya Çıkan Tema ve Alt Temalar

\begin{tabular}{lll}
\hline No & Temalar & Alt temalar \\
\hline 1 & Sessizlikle ilgili eğitim & $\begin{array}{l}\text { Psikolojik danışmanların eğitimi } \\
\text { Danışanların eğitimi }\end{array}$ \\
\hline 2 & Sessizlik süreci & $\begin{array}{l}\text { Sessizliği yönetme } \\
\text { Sessizliğe tepkiler }\end{array}$ \\
\hline 3 & Sessizliğe tolerans & $\begin{array}{l}\text { Yaklaşık sessizlik süresi } \\
\text { Sessizliği bozmak }\end{array}$ \\
\hline 4 & \multirow{2}{*}{ Sessizliğin kullanımı } & $\begin{array}{l}\text { Danışma aşamalarında kullanımı } \\
\text { Sessizliğin kaynağı }\end{array}$ \\
\hline 5 & \multirow{2}{*}{ Sessizliğin katkıları } & $\begin{array}{l}\text { Danışana katkılar } \\
\text { Psikolojik danışmana katkılar } \\
\text { Psikolojik danı̧̧̧ma sürecine katkılar }\end{array}$ \\
\hline
\end{tabular}

\section{Sessizlikle İlgili Eğitim Temasına İlişkin Bulgular Psikolojik Danışmanların Eğitimi}

Alt tema bulguları incelendiğinde psikolojik danışmanlara, lisans ve yüksek lisans eğitimleri sırasında sessizliğe özgü bir spesifik eğitim verilmediği anlaşılmaktadır. Ancak katılımcıların büyük çoğunluğu (n=11; \%78.57) özellikle psikolojik danışma ilke ve teknikleri ile bazı uygulamalı derslerde sessizlik üzerinde durulduğunu ifade etmektedirler. Üç katılımcı (\%21.43) ise üniversite eğitimlerinde sessizlikten hiç bahsedilmediğini belirtmişlerdir. Katılımcılardan biri (K8) lisans düzeyinde aldığı eğitimle ilgili olarak "Daha sonra özel bir eğitim almadım. Ama dersin içerisinde sessizliğin kullanılmastyla ilgili konular işlendiğinde, uygulamalarda bunu yaptık." demiştir. Başka bir katılımcı (K1) ise, "Hocamız şöyle anlatmıştı, eğer sessizlik oluşuyorsa sessizliği bozmak için uğraşmayın, derdi. Çünkü oradaki sessizlikte danışan kendini ifade etmek için bir şeyler düşünüyor olabilir. Her şey olabilir, derdi. O yüzden sessizliği bozmak için konuşmaya çalışmayın, danışanın sessizliği bozmasına izin verin derdi." şeklinde ifade etmiştir. Ancak alınan bu eğitimlerin yeterli düzeyde olmadığı anlaşılmaktadır. Katılımcılardan biri (K8) bu hususu "Lisansta ya da yüksek lisansta sessizliğin kullanılmasina, değerlendirilmesine yönelik yeterli bilgi verilmedi. Genel anlamda sessizlik şudur, faydalıdır, zararlıdır, o kadar. Danışma ortamında sessizlik olur, siz o sessizliği takip edin, duruma göre hareket edersiniz gibi yuvarlak bir ifade sadece.". Lisans ve lisansüstü düzeyde sessizlikle ilgili sınırlı seviyede bilgi edinmenin dışında katılımcıların tamamı üniversite eğitimi sonrasında sessizlikle ilgili özel bir eğitim almadıklarını belirtmişlerdir. 


\section{Danışanların Eğitimi}

Danışanların sessizliğe ilişkin eğitimiyle ilgili alt tema bulguları incelendiğinde katılımcıların tamamının, danışanlarına sessizliğin kullanımına ilişkin bir eğitim vermedikleri, sessizliğin süreç içerisinde kendiliğinden oluşmasına izin verdikleri görülmüştür. Bir katılımc1 (K4) bunu, "Yani özellikle sessizlikle alakadar herhangi bir bilgilendirme yapmiyorum. O genelde danışmanın bir parçası şeklinde devam ediyor. Hani danışmayla bütünleşik bir şekilde devam ediyor. Özellikle danışana şunu kullanacağız diye bir açıklama yapmıyorum." şeklinde ifade etmiştir. Benzer bir durumu, sessizliğe ilişkin önceden bilgi vermenin zararlı olabileceğini düşünen başka bir katılımcı (K1) şöyle ifade etmiştir: "Bu konuda kesinlikle bilgi vermem. Ĕger sessizlik anlar şöyle anlardır dediğimiz zaman işte o zaman danışan bunu kullanmaya başlayabilir diye sessizlikle ilgili hiçbir bilgi vermemek gerekir."

\section{Sessizlik Süreci Temasına İlişkin Bulgular Sessizliği Yönetme}

Alt tema bulguları incelendiğinde katılımcıların sessizliğe ilişkin genel bir yönetim şekillerinin olmadığı anlaşılmaktadır. Sessizliğin yönetimi danışana ya da sessizlik nedenine göre değişmekte ve bu süreçte genel psikolojik danışma becerileri kullanılmaktadır. Ayrıca çoğunlukla sessizliğin başında yönetimin danışana bırakıldığı, süre uzadığında ise psikolojik danışmanın yönetimi devraldığı anlaşılmaktadır. Sessizlik sürecini yönetmeyi orkestra şefliğine benzeten bir katılımcı (K13) bunu şu şekilde açıklamıştır. "Duruma göre değişiyor. Hangi konuyla alakall, yani niçin sessiz kalyyor, bu önemli. Ĕger ciddi bir duygu paylaşımı varsa, yaşayıp bitirmesini beklemek zorundasınız. Klsa süreli de olsa onun yönetmesine izin veriyorsunuz." Başka bir katılımc1 ise (K7) sessizliği nasıl yönettiğini, "Danışanı gözlemlemeyi tercih ediyorum. Danışanın sözel olmayan tepkileri de var tabii. Beden dili var ve belirli bir süre geçmiş, artık danışan danışmayı devam ettirmiyor, sessizliği bozmuyorsa uygun, empatik cümlelerle yeniden danısmayı başlatmayı veya sürdürmeyi sağlamaya çalışıyorum." şeklinde ifade etmiştir. Aynı katılımcı sessizliği yönetme becerisinin zamanla öğrenildiğini şöyle açılamıştır: "Kendi tecrübemden yola çıkarak söylüyorum, zamanla oluşacak bir şey. Daha doğrusu danışmanın her aşaması böyle. Yani zaman içinde, uygulaya uygulaya kazanacağınız bir şey."

\section{Sessizliğe Tepkiler}

$\mathrm{Bu}$ alt tema psikolojik danışmanın sessizlik sürecindeki duygu, düşünce 
ve davranışlarıyla ilgilidir. Bazı katılımcılar ( $\mathrm{n}=3 ; \% 21.43)$ bu süreçte danışanın aklından geçenler ile ilgili merak duygusu yaşadıklarını ifade etmişlerdir. Katılımcılardan biri (K2) yaşadığ 1 bu duyguyu "Merak... Devamının nasıl geleceğine dair merak." şeklinde ifade etmiştir. Bazı katılımcılar ise ( $\mathrm{n}=4$; \%28.57) danışan o sırada ne hissediyorsa kendilerinin de benzer duyguları yaşadıklarını belirtmişlerdir. Bir katılımcı (K5) bunu şu şekilde belirtmiştir: "Tam olarak çaresizlikse çaresizlik, umutsa umut. Danışanın içinde bulunduğu duruma göre değişiyor." Bunların dışında bir katılımcı sessizlik sürecinde gerildiğini, bir katılımcı ise sıkıldığını ifade etmiştir. Bu tema ile ilgili verilen cevaplar incelendiğinde, katılımcıların yarıya yakınının $(n=6 ; \% 42.86)$ ise bu süreçte yaşadıkları duygunun farkında olmadıkları anlaşılmaktadır.

Katılımc1ların sessizlik sürecindeki düşünceleri incelendiğinde, çoğunluğunun ( $\mathrm{n}=10 ; \%$ 71.43) danışan ve süreçle ilgili konulara odaklandıkları belirlenmiştir. Bazı psikolojik danışmanlar $(\mathrm{n}=7 ; \% 50)$ ise bu süreçte sessizliğe hangi tepkilerle son vereceklerini düşündüklerini ifade etmişlerdir. Süreçle ilgili hususlara odaklanan bir katılımc1 (K14) bunu "O sürece kadar danışanla benim aramda geçen şeyleri toparlarım. O sürece kadar olanları düşünürüm." şeklinde ifade ederken, kendi vereceği tepkiye odaklanan başka bir psikolojik danışman (K7) bunu "Danışanı gözlemlerim, o sessizlik danışan tarafindan sonlandırlmayacaksa kafamdan sessizliği sonlandiracak senaryolar kurgulamaya başlarım. Yani hangi cümlelerle girmeliyim o sessizliğin sonucunda, onu kurgularım." şeklinde ifade etmiştir.

Katılımcıların hemen hemen tamamının sessizlik anlarında danışanları rahatsız etmeyecek davranışlar sergilemeye çalıştığı görülmektedir. Tüm dikkatin kendi üzerinde olduğunu düşünen, danışanın sessizliği bozmak zorunda hissedebileceğini düşünen iki katılımcı, bu süreçte elindeki kalemle ya da masadaki dosyayla uğraşma gibi davranışlar gösterdiklerini rapor etmişlerdir. Böylece danışanın sessizlik sürecini daha rahat yaşayabileceğini ifade etmişlerdir. Bunun dışında diğer katılımcılar danışanı rahatsız etmeyecek şekilde göz kontağını devam ettirmeye çalıştıklarını, bu süreçte beden dillerine daha çok dikkat ettiklerini bildirmişlerdir. Mesela bir katılımcı bunu (K13) "Yani ĕger ki sessiz kalmanı gereken bir zamansa, beden dilinizin de sessiz olmast gerekiyor. Ağzınız susuyor; ama beden diliniz konuşuyorsa karşınızdakine belki düşünme ya da anlatma firsatı vermiyor olabilirsiniz." şeklinde ifade ederken, başka bir katılımcı (K8) "Kendimi direkt danışana odaklarım, rahat 
bir pozisyonda durarak, danışan da bendeki rahatllğı görerek kendi iç dünyasiyla daha rahat konuşmasını ve daha sonra bunun danışma ortamına gelmesi için zemin hazırlarım. Kendimi rahat gösteririm ki danışan da rahat hareket edebilsin." şeklinde ifade etmiştir.

\section{Sessizliğe Tolerans Temasına İlişkin Bulgular Sessizlik Süresi}

Sessizlik süresi alt teması bulguları incelendiğinde psikolojik danışma oturumlarında gerçekleşen ortalama sessizlik süresi bazı katılımcılar için $(\mathrm{n}=3$; \%21.43) 1 dakikadan az, bazıları için ( $\mathrm{n}=9$; \%64.29) 1-5 dakika arası, bazıları için ise ( $\mathrm{n}=2 ; \% 14.29) 5$ dakikadan uzundur. Sessizlik süresinin dan1şanların durumuna ya da sorun alanına göre değiştiği anlaşılmaktadır. Özellikle daha yüzeysel konularla ilgili gerçekleştirilen psikolojik danışmalarda sessizlik sürelerinin kısa olduğu görülmektedir. Ayrıca okul ortamının da sessizlik süresini etkileyen bir değişken olduğu görülmektedir. Bir katılımc1 (K5) bu durumu “... Alan çok buna müsait bir alan değil, 2 öğretmen çalışıyoruz, aynı odayı paylaşıyoruz. 900 kişilik bir mevcut var. Ne kadar odamızın müsait olduğunu düşünsek de bölünmeler olabiliyor. Zamanı verimli kullanmak anlamında çok fazla tolerans gösteremiyoruz." ş̧eklinde belirtmiştir.

\section{Sessizliği Bozmak}

$\mathrm{Bu}$ alt temaya ilişkin bulguları incelendiğinde katılımcıların yarıya yakını (n=6; \%42.86) sessizliği çoğunlukla kendilerinin bozduğunu belirtirken, bazıları ( $\mathrm{n}=5$; \%35.71) daha çok danışanlarının bozduğunu ifade etmişlerdir. Üç katılımcı ise bir süre danışana izin verdiklerini, eğer danışan bozmazsa kendilerinin bozduğunu bildirmişlerdir. Genel olarak sessizliği bozmanın danışanın durumu ya da sorun alanına göre değiştiği görülmektedir. Bir katılımcı (K3) bu durumu "Ĕger danışanım içine kapanmaya başlamışsa, iletişimi kapatmaya çalışıyorsa, o sessizliği ben bozarım. Ama baklyorum ki bu sessizlik danışanımın kendini açmasına vesile oluyorsa bırakıyorum o zaman." şeklinde ifade etmiştir. İlkokulda çalışan başka bir katılımcı (K10) bunu "Niye danışmaya gelmiş. Ona göre değişir aslında. Mesela ailevî, ciddi bir sıkıntıysa beklerim. Ama basit düzeyde bir problemse, yani okulda yaşanan tarzda, arkadaşlık iliş̧ileriyle alakalı olabilir, orada çok beklemem." şeklinde belirtmiştir. Aynı katılımcı küçük çocuklarla çalışırken sessizliği daha erken bozabildiğini şöyle açıklamıştır: "Mesela ağllyor öğrenci ya da sürekli bir şeyler anlatma ihtiyacı hissediyor. Orada ben de illa ki cevap verme ihtiyacı duyuyorum. Yani ağlasın rahatlasın kendi hâline kalsın, onu yanlış buluyorum." 
Son olarak, sessizliğin bozulmasının psikolojik danışmanın meslekî deneyiminden etkilendiği görülmektedir. On beş yıldır okul psikolojik danışmanı olarak çalışan bir katılımcı (K7) bu durumu "Illk yıllarda genelde ben o sessizliği bozan taraftım. Zaman içinde tecrübe kazandıkça danışana daha çok süre tanıyorsunuz. Ama ilk yıllarda biraz aceleci davranıyorduk. Şimdi fark ediyorum." şeklinde belirtmiştir.

\section{Sessizliğin Kullanımı Temasına İlişkin Bulgular Sessizliğin Psikolojik Danışma Aşamalarında Kullanımı}

Alt tema bulguları incelendiğinde, liselerde ve RAM'da çalışan katılımcıların büyük çoğunluğu $(\mathrm{n}=7$; \%50) sessizliğin psikolojik danışma sürecinin ilk aşamalarında fazla kullanılmadığını, psikolojik danışman-danışan ilişkisi güçlendikten sonra daha çok kullanıldığını belirtmektedirler. İlkokulda, daha çok küçük çocuklarla çalışan iki katılımcı ise psikolojik danışma sürecinin başlangıç aşamalarında sessizliğin daha çok oluştuğunu ifade etmişlerdir. Benzer şekilde, özellikle disiplin sorunlarının fazla yaşandığı liselerde sessizliğin psikolojik danışma sürecinin başlarında daha fazla oluşabildiği dikkat çekmektedir. Örneğin katılımc1lardan biri (K12) bu durumu şöyle belirtmiştir: "Arada bir, bir iki dakika sessiz kalarak, birbirimizi tartıp ölçerek konuşmayı devam ettirebiliyoruz. Bu ilk aşamalarda güvenin oluşmasına yardim ediyor." Katılımcıların ifadeleri değerlendirildiğinde, psikolojik danışma sürecinin ilk aşamalarında psikolojik danışman-danışan ilişkisinin kurulmasında rol oynayan sessizliğin, sonraki aşamalarda danışanın kendini açmasını, duygularını ifade etmesini, içgörü geliştirmesini desteklemek ve sorumluluk almasını teşvik etmek amacıyla kullanıldığg görülmektedir. Bir katılımcı (K6) bu konuyu şöyle ifade etmiştir:

\footnotetext{
"Biz karşımızdakinden akıl almayı seven bir toplumuz, yapımız bu. Danışmaya gelenler de problemini ifade eder, sizden bekler çözmenizi. Biz yansıtma yaptığımızda, ona çok tatmin edici gelmiyor başta. Sessizlikle kendini ifade etme zorunluluğu oluşuyor. Bugüne kadar derdini hep başkasına anlatmış ve fikirler almış. İlk defa kendi ayakları üzerinde durmayı ögrenecek."
}

Bunların dışında, bazı katılımcılar ( $\mathrm{n}=5$; \%35.71) kendini ifade edemeyen, içine kapanık danışanlar ve küçük çocuklarda zaman zaman sessizliği kullanmaktan kaçındıklarını belirtmişıerdir. İki katılımcı, psikolojik danışmanın yetersizliği anlamına gelebileceğini düşündüklerinden, sessizliği dikkatli kullandıklarını belirtmişlerdir. Bir katılımcı ise sessizliği fazla kullanmanın danışanda anlaşılmadığı hissi uyandırabileceğini ifade etmiştir. Son olarak, 
katılımcıların yarısı $(\mathrm{n}=7 ; \% 50)$ sessizliği bir teknik olarak, diğerleri ise süreç içerisinde kendiliğinden gelişen bir durum olarak algıladıklarını rapor etmektedirler.

\section{Sessizliğin Kaynağı}

$\mathrm{Bu}$ alt tema bulguları incelendiğinde, katılımcıların çoğunluğu $(\mathrm{n}=10$; \% 71.43) danışana ya da sorunun niteliğine göre değişmekle birlikte sessizliğin kaynağını büyük oranda danışan olarak görmektedirler. Diğer katılımcılar ise sessizliğin kaynağının kendileri olduğunu, danışanın sorumluluk almasını ve problem üzerinde daha fazla düşünmesini desteklemek için sessizliği kullandıklarını ifade etmektedirler. Bir katılımcı ise (K9) psikolojik danışmanın da zaman zaman sessizliğe ihtiyaç duyduğunu şöyle belirtmiştir: "Yasla ilgili bir psikolojik danışmaydı. Yakın zamanda bir yakınımı kaybetmişstim. Orada bir sessizlik olmuştu ve benden kaynaklanmışt.."

\section{Sessizliğin Katkıları Temasına İlişkin Bulgular Psikolojik Danışmana Katkıları}

Sessizliğin psikolojik danışmana katkıları alt teması ile ilgili bulgular incelendiğinde, zihnini dinlendirmeye ve süreci gözden geçirmeye imkân sağladığı, psikolojik danışmana danışanını daha iyi tanıma fırsatı verdiği belirtilmektedir. Sessizlik bunun dışında psikolojik danışmanların beden dilleriyle danışanlarına mesaj iletmelerine de yardım etmektedir. Bir katılımcı (K12) bu konuda "Ben sabırlıyım, seni beklerim, seni anlamaya çalışıyorum, sana değer veriyorum şeklinde mesajlar iletebiliyorum. Böyle olduğu zaman en azından diyor ki karşıdaki beni suçlamıyor, suçlamadiğı zaman da rahatlıkla konuşabiliyor." demiştir.

\section{Danışana Katkıları}

$\mathrm{Bu}$ alt tema kapsamında danışanın kendisiyle yüzleşmesi ve sorumluluk almaya başlaması, içgörü geliştirmesi, rahatlaması, kendisini daha iyi tanıması, kendini açmasına firsat sağlaması gibi hususlar rapor edilmiştir. Bir katılımcı (K7) bu konuda "Sessizlik olduğu anda belki dışa dönük iletişim bitiyor; ama içe dönük iletişim bitmiyor. Ben onu hem gözlemlerimden biliyorum, hem kendi yaşamımdan. O iç konuşmaların devam etmesinin anlamlı bir katklsı var." demiştir. Başka bir katılımc1 (K5) ise görüşlerini "Kendilerini tanıyorlar, sorunla ilgili kendi çözümlerini görebiliyorlar, güçlerini fark edebiliyorlar. Sadece karşı taraftan bilgi almak değildir rehberlik, bunu fark ediyorlar." şeklinde ifade etmiştir. Sessizliğin danışanlara farklı bir katkısı ise başka bir katılımcı (K14) tarafından "Bazen danışanlar sinirli de olabiliyor. Onların 
yatışmasını da sağlıyor." şeklinde belirtilmiştir.

\section{Psikolojik Danışma Sürecine Katkıları}

Sessizliğin psikolojik danışma sürecine katkıları alt teması bulguları, sessizliğin psikolojik danışma sürecinin ayrılmaz bir parçası olduğunu ortaya koymaktadır. Katılımcılar sessizliği, sürecin işlediğinin bir göstergesi olarak ele almışlardır. Ayrıca sessizlik sonrasında sürecin çok daha etkili bir şekilde ilerlediği ve verimliliğin arttığı vurgulanmıştır. Bir katılımc1 (K6) bu konuda "Danışma sürecine özellikle o kırılma noktalarının aşılmasına çok yardımcı olduğunu düşünüyorum. O sessizlik süreçlerinden sonra sizden artık destek beklemiyor, kendi kendini açmaya başlıyor." demiştir. Başka bir katılımcı (K13) ise görüşlerini "Etkili ve yerinde kullanılmış bir sessizlik çok iyi sonuç verebilir size. Danışmanın ileriki süreçlerinde ya da o süreçte de problemin asıl kaynağını bulmanıza yardımcı olabilir." şeklinde açıklamıştır.

\section{Tartışma}

Nitel desende yapılan bu çalışmada, psikolojik danışmanların danışma oturumlarında yaşanılan sessizlikle ilgili deneyimlerin incelenmesi amaçlanmıştır. Katılımcıların ifadelerinden yola çıkılarak 5 tema, 11 alt tema elde edilmiştir. Genel olarak alanyazınla uyumlu bulgulara ulaşılmıştır.

\section{Sessizlikle İlgili Ĕgitim}

Bulgular incelendiğinde, katılımcıların tamamı bir mikro beceri olarak sessizliğin kullanımına yönelik eğitim almadığını, ancak büyük bir çoğunluğu (\%78) sadece psikolojik danışma ilke ve teknikleri dersinde kısaca bahsedildiğini ifade etmişlerdir. Benzer şekilde, katılımcıların tamamı danışanlarını oturumlarda sessizliğin kullanımı konusunda eğitmediklerini, bazıları bunun süreç içerisinde gelişen doğal bir tepki olduğunu, sessizliğin kullanımı konusunda danışanı bilgilendirmenin zararlı olacağını ve onu yönlendirebileceğini belirmişlerdir. Araştırmaya katılan psikolojik danışmanların ifadelerinden anlaşıldığı kadarıyla kendileri sessizliğin kullanımı ve işlevi konusunda yeterince bilgiye/deneyime sahip olmadıkları için danışanlarını da eğitmenin gerekli olmadığını düşünmüş olabilirler. Sessizliğin danışma sürecinde kullanımına yönelik danışmanların deneyimlerinin incelendiği bir çalışmada (Ladany ve ark., 2004), katılımcıların büyük bir çoğunluğunun sessizliğin kullanımını aldıkları eğitimlerden daha çok klinik deneyimler ve süpervizyonlardan öğrendikleri bulunmuştur. Aynı çalışmada psikolojik danışmanların genel olarak danışanlarını sessizliğin kullanımı konusunda eğittiklerini ve bu sayede danışanlarının sessizlik anlarında daha az direnç gösterdiklerini belirmişlerdir. 
Hill, Thompson ve Ladany (2003) çalışmasında da benzer bulgulara ulaşı1mıştır. Çalışmada, ayrıca katılımcıların büyük bir çoğunluğunun sessizliği deneyim kazandıkça daha fazla kullandıklarını bulmuşlardır.

\section{Sessizlik Süreci}

Araştırmaya katılan psikolojik danışmanlar genel olarak sessizliği yönetme konusunda net bir yöntem kullanmaktan daha çok danışanın durumuna göre tepkide bulunduklarını belirmişlerdir. Sessizlik anlarında psikolojik danışmanların ne tür tepkilerde bulunduklarına yönelik bulgular incelendiğinde, büyük bir çoğunluğunun (\%71) bir sonraki aşamada ele alacağı konulara odaklandığı, bir kısmının ise sessizliği nasıl bozacağıyla ilgili yöntemleri düşündüğü görülmektedir. Ayrıca bulgular, psikolojik danışmanların sessizlik anlarında danışanları rahatsız etmemek için bir şeylerle meşgul olma, onlarla empati kurma ve onları gözlemleme gibi tepkiler ortaya koyduklarını göstermektedir. Alanyazında sessizliğin kullanımıyla ilgili doğrudan psikolojik danışmanların görüşlerine dayalı çalışmalar sınırlı olmakla birlikte yapılan ça11şmalarda (Hill, Thompson ve Ladany, 2003; Ladany ve ark., 2004) benzer bulgulara ulaşılmıştır. Bu çalışmalarda, psikolojik danışmanların sessizlik anlarında daha çok danışanla empati kurma, gözlem yapma, bir sonraki aşamada konuşacaklarını toparlama, danışan ve danışma süreci hakkında düşünme ve hiçbir şey yapmadan danışanın sessizliği etkili bir şekilde kullanmasını sağlamaya çalışma gibi tepkiler ortaya koydukları belirtilmiştir. Görüldüğü üzere sessizlik anları boş geçen bir süreç değil, danışmaya katkı sağlayacak şekilde değerlendirilen bir firsat olarak kullanılmaktadır.

\section{Sessizliğe Tolerans}

Bu tema altında sessizliğin süresi ve nasıl, kim tarafından bozulduğuyla ilgili alanyazınla uyumlu bulgulara ulaşılmıştır. Katılımcıların büyük bir çoğunluğu danışma oturumlarında sessizlik süresinin 1-5 dakika arasında değiştiğini ifade etmiştir. Katılımcılardan bazıları ise sessizliğin 1 dakikadan daha az olduğunu, bazıları da 5 dakikadan fazla olduğunu belirmiştir. Ayrıca katılımcıların ifadelerinden, sessizlik süresinin danışanın durumuna, danışma ortamına ve problem durumuna göre değişiklik gösterdiği anlaşılmaktadır. Her ne kadar Hill, Carter ve O'Farrell (1983) sessizliğin bir oturum süresinin \%5'inden daha az olduğunu öne sürse de bu çalışmada katılımcıların danışma oturumlarında sessizliğin süresiyle ilgili bir standarda sahip olmadıkları görülmektedir. Daha önceki araştırmalarda (Sharpley, 1997; Sharpley, Munro ve Elly, 2005) sessizlik süresinin psikolojik danışman-danışan arasındaki ilişkiye 
bağlı olarak değiştiğini ve iyi bir kaynaşmanın (rapport) olduğu oturumlarda sessizlik süresinin daha fazla olduğu belirtilmektedir.

Bulgulara göre, sessizliğin kimin tarafindan bozulduğu konusunda belirgin bir standart olmadığı, daha çok danışanın durumuna, problemin türüne ve psikolojik danışmanın deneyimine göre değiştiği görülmektedir. Örneğin bir psikolojik danışman, deneyim kazandıkça sessizliği bozma konusunda acele etmediğini ve genellikle inisiyatifi danışana bıraktığını belirtirken, bazı psikolojik danışmanlar önemli olmayan konuların konuşulduğu oturumlarda veya danışanın sessizliği direnç olarak kullanmaya başladığı durumlarda sessizliği kendilerinin bozduğunu belirmişlerdir. Sessizliği sonlandırmayla ilgili bulguların genel olarak alanyazınla uyumlu söylenebilir. Barber (2009), psikolojik danışmanların sessizliği yönetme becerilerinin deneyimlerine bağlı olarak arttığını bulmuştur. Ladany ve arkadaşları (2004), psikolojik danışmanların sessizliği bozma konusunda net bir tutum ortaya koymadıklarını, dan1şanlar sessizliği etkili bir şekilde kullanmadıklarında ve sessizlikten rahatsız olduklarında sürece müdahale ettiklerini bildirmişlerdir. Sharpley, Munro ve Elly (2005) danışan tarafından başlatılan ve sonlandırılan sessizliğin olduğu oturumlarda psikolojik danışman ve danışan arasında daha fazla kaynaşmanın yaşandığını bulmuşlardır.

\section{Sessizliğin Kullanımı}

Psikolojik danışmanların yarıdan fazlası sessizliği ilk oturumlardan ziyade, ilerleyen oturumlarda ve özellikle psikolojik danışman-danışan arasında ittifak kurulduktan sonra kullanmayı tercih ettiklerini belirtmişlerdir. Bunun yanında bazı danışmanlar, daha küçük yaş gruplarıyla yaptıkları danışma oturumlarda ve disiplin sorunları nedeniyle danışma alan danışanlarla çalışırken sessizliğin ilk başlarda daha fazla olduğunu ifade etmişlerdir. Danışmanlar terapötik ittifak kurulduktan sonra sessizliği özellikle, danışanın kendisini açmasını, duygularını ifade etmesini, içgörü geliştirmesini desteklemek ve sorumluluk almasına yardımcı olmak için kullanmayı tercih etmişlerdir. Diğer taraftan, psikolojik danışmanlar kendini ifade etmekte zorlanan, içe kapanık ve yaşı küçük olan danışanlarla çalışırken sessizliğin kullanımına daha az başvurmuşlardır. Ayrıca psikolojik danışmanların yaklaşık yarısı sessizliği bir teknik olarak kullanırken, diğerleri süreç içerisinde gelişen bir durum olarak değerlendirmişlerdir. Sessizliğin kullanım nedenleri ile ilgili bulguların genel olarak alanyazınla uyumlu olduğu söylenebilir. Örneğin, Ladany ve arkadaş- 
ları (2004) ve Hill, Thompson ve Ladany (2003) psikolojik danışmanların büyük bir çoğunluğunun sessizliği oturumların başında ve başlangıç evresinde kullanmayı çok fazla tercih etmediklerini belirtmişlerdir. Bunun yanında psikolojik danışmanların sessizliği, danışanları konuşmaya teşvik etmek ve sorumluluk almalarını sağlamak için kullandıkları ifade edilmiştir. Bu çalışmada ve önceki benzer çalışmalardaki bulgular birlikte değerlendirildiğinde, danışma sürecinde sessizliğin sadece geleneksel psikanaliz yaklaşımı tarafından bir direnç (Arlow, 1961; Hadda, 1991) ya da geri çekilme (Shafii, 1973; Stringer, Levitt, Berman ve Mathews, 2010) olarak değil, Levitt'in (1998, 2001a) belirttiği gibi üretici sessizlik olarak da işlevinin olduğu söylenebilir.

$\mathrm{Bu}$ çalışmada elde edilen önemli bulgulardan birisi de sessizliğin daha çok danışandan kaynaklandığıdır. Psikolojik danışmanların çok azı, sessizliği daha çok kendilerinin tercih etiğini belirmiştir. Diğer taraftan, Sharply, Munro ve Elly'nin (2005) belirttiği gibi sessizliğin danışan tarafından başlatılması ve sonlandırılması terapötik ittifaka katkı sağlasa da, özellikle direnç gösteren, anlaşılmadığını düşünen (Levitt, 2001a, 2001b) ve tehdit altında hissettiği benliğini korumak isteyen danışanlar (Sabbadini, 1986) sessizliği daha fazla kullanmaktadırlar. Tindall ve Robinson'un (1947) yaptığı çalışmada danışanlar sessizliği psikolojik danışmanlara göre daha fazla kullanmakla birlikte, kullanım nedenleri incelendiğinde danışanlar sadece sorudan sonra cevap vermek, yeni bir düşünceye geçmek için değil aynı zamanda direnç gösterisi olarak da kullanmaktadırlar. Dolayısıyla, sessizliğin kimin tarafından fazla kullanıldığı kadar, ne amaçla kullanıldığının bilinmesi de önemlidir. Özetle, sessizliğin kaynağının daha çok danışan olduğunu gösteren araştırma bulguları alanyazınla uyumlu görülmektedir. Ancak danışan tarafından ortaya konan bu sessizliklerin ne kadarının direnç ifadesi olduğu ve bunların terapötik ittifaka etkileri, bu konuda ileride gerçekleştirilecek çalışmalarla incelenebilir.

\section{Sessizliğin Katkıları}

Bulgular, sessizliğin psikolojik danışmanlara, danışanlara ve danışma sürecine çeşitli katkılar sağladığını işaret etmektedir. Örneğin, psikolojik danışmanlar sessizlik sürecinde zihinlerini dinlendirdiklerini ve süreci gözden geçirmeye firsat yakaladıklarını belirtmişlerdir. Bu çalışmada doğruda danışanlar açısından sessizliğin kullanımı ele alınmamakla birlikte, psikolojik danışmanların ifadelerine göre, sessizliğin danışanlara sorumluluk alma, kendisiyle yüzleşme, içgörü kazanma ve rahatlama gibi katkıları olmuştur. Bunların yanında, katılımcılar sessizliğin danışma sürecine de katkı sağladığını ve daha 
verimli bir ortam sağladığını belirmişlerdir. Sessizliğim katkılarıyla ilgili bulgular genel olarak daha önce yapılan çalışmalarla (Levitt, 2001a, 2001b; Sharpley, 1997; Sharpley, Munro ve Elly, 2005; Urlic, 2010) uyumludur.

\section{Sonuçlar}

Çalışmadan elde edilen bulgular genel olarak değerlendirildiğinde, sessizliğin konuşma aralarındaki boşluktan (Weiss, 1997) daha fazla anlam ifade ettiği söylenebilir. Bulgular, aynı zamanda sessizliğin sadece direnç, geri çekilme ya da ego savunması olarak değil; düşüncelere odaklanma, farkındalığ artırma ve zihni dinlendirme işlevlerini ortaya koymuştur. Diğer bir ifadeyle bu çalışmanın sonuçları Levitt'in (1998, 2001a), sessizlikle ilgili sınıflamasında belirttiği engelleyici (direnç gösterme), üretici (içgörü kazanma) ve nötr sessizlik (bir sonraki konuya geçme) türlerinin danışma sürecinde yaşandığını göstermiştir.

Bu çalışma bilindiği kadarıla Türkiye'de sessizlik konusunda psikolojik danışmanların deneyimlerini inceleyen ilk çalışma olmakla birlikte bazı sınırlılıklara sahiptir. Öncelikle, sessizliğin danışma sürecindeki kullanımı konusunda sadece psikolojik danışmanların bakış açısına yer verilmiştir. Bu konuda daha derinlemesine bilgi almak için danışanlarında eş zamanlı birlikte görüşlerinin ve deneyimlerinin incelenmesi faydalı olacaktır. Ayrıca sessizlik anları ve kimin daha fazla sessizliği kullandığı sadece algıya dayalı olarak belirlenmeye çalışılmıştır. Daha kesin sonuçlara ulaşmak için görsel-işitsel danışma kayıtlarının incelenmesi daha kat'i bilgi alınmasına katkı sağlayacaktır. Nitel desende yapılan bu çalışmada sınırlı sayıda psikolojik danışmanla görüşme yapılmıştır. Bu nedenle bu konuda nicel çalışmalar ile daha fazla kişiye ulaşarak sonuçların genellenebilirliği artırılabilir. Son olarak, bulgulara göre katılımcılar sessizlik konusunda spesifik bir eğitim almadıkları, bu konuda becerilerini deneyimleri sayesinde geliştirdikleri anlaşılmaktadır. Bu nedenle, psikolojik danışmanlık eğitiminde sadece genel danışma becerileri üzerine değil, sessizlik gibi mikro becerilere yönelik teorik derslerde ve psikolojik danışma uygulamaları dersi (süpervizyon) kapsamında kuramsal ve uygulamalı eğitimler verilebilir.

\section{Kaynakça}

Arlow, J. A. (1961). Silence and the theory of technique. Journal of the American Psychoanalytic Association, 9, 44-55.

Barber, T. (2009). Newly qualified counsellors' experience of silence within 
the therapeutic setting. Yayınlanmamış yüksek lisans tezi, Roehamtom Üniversitesi.

https://www.academia.edu/362080/Silence_in_Psychotherapy_Newly_qualified_counsellors_experience_of_silence_within_the_therapeutic_setting

Berg, B. L. (2009). Qualitative research methods for the social sciences. Boston: Allyn \& Bacon.

Bravesmith, A. (2012). Silence lends integrity to speech: Transcending the opposites of speech and silence in the analytic dialogue. British Journal of Psychotherapy, 28(1), 21-34.

Creswell, J. W. (2013). Nitel araştırma yöntemleri beş yaklaşıma göre nitel araştırma ve araştırma deseni. (M. Bütün, ve S. B. Demir Çev. Ed.). Ankara: Siyasal Kitabevi. (Orijinal çalışma basım tarihi 2013.)

Davies, D. ve Dodd, J. (2002). Qualitative research and the question of rigor. Qualitative Health Research, 12(2), 279-289.

Denham-Vaughan, J. ve Edmond, V. (2010). The value of silence. Gestalt Journal of Australia and New Zealand, 6(2), 5-19.

Endrass, B., Rehm, M., André, E. ve Nakano, Y. I. (2008, Ocak). Talk is silver, silence is golden: A cross cultural study on the usage of pauses in speech, Proceedings of the IUI workshop on Enculturating Conversational Interfaces içinde. $13^{\text {th }}$ International Conference on Intelligence User Interfaces, İspanya.

Frankel, Z. E., Levitt, H. M., Murray, D. M., Greenberg, L. S. ve Angus, L. (2006). Assessing silent processes in psychotherapy: An empirically derived categorization system and sampling strategy. Psychotherapy Research, 16(5), 627-638.

Freud, S. (1912). Recommendations to physicians practicing psycho-analysis. J. Strachey, (Ed.), The standard edition of the complete psychological works of Sigmund Freud (12. cilt) içinde (109-120). London: Hogarth Press.

Gale, J. ve Sanchez, B. (2005). The meaning and function of silence in psychotherapy with particular reference to a therapeutic community treatment programme. Psychoanalytic Psychotherapy, 19(3), 205-220. 
Gans, J. S. ve Counselman, E. F. (1999). Silence in group psychotherapy: A powerful communication. International Journal of Group Psychotherapy, 50, 71-86.

Golafshani, N. (2003). Understanding reliability and validity in qualitative research. The Qualitative Report, 8(4), 597-606.

Hadda, J. (1991). The ontogeny of silence in an analytic case. The International Journal of Psycho-Analysis, 72(1), 117-30.

Hill, C. E, Carter J. A. ve O'Farrell, M. K. (1983). A case study of theprocess and outcome of time-limited counseling. Journal of Counseling Psychology, 30(1), 3-18.

Hill, C., Thompson, B. ve Ladany, N. (2003). Therapist use of silence in therapy: A survey. Journal of Clinical Psychology, 59, 513-524.

Johnson, B. ve Christensen, L. (2014). Eğitim araştırmaları, nicel, nitel ve karma yaklaşımlar (S. B. Demir, Çev. Ed.). Ankara: Eğiten Kitap. (Orijinal çalışma basım tarihi 2012.)

Krefting, L. (1991). Rigor in qualitative research: The assessment of trustworthiness. American Journal of Occupational Therapy, 45(3), 214-222.

Ladany, N., Hill, C. E., Thompson, B. J. ve O'Brien, K. M. (2004). Therapist perspectives on using silence in therapy: A qualitative study. Counselling and Psychotheraphy Research, 4(1), 80-89.

Lambert, M. (1992). Psychotherapy outcome research: Implications for integrative and eclectic therapists. J. C. Norcross ve M. R. Goldfried, (Ed.), Handbook of psychotherapy integration içinde (94-129). New York: Wiley.

Lane, R. C., Koetting, M. G. ve Bishop, J. (2002). Silence as communication in psychodynamic psychotherapy. Clinical Psychology Review, 22(7), 1091-1104.

Levitt, H. (1998). Silence in psychotherapy: The meaning and founction of pause. Yayınlanmamış doktora tezi, York Üniversitesi, Ortanto, Toronto.

Levitt, H. M. (2001a). Sounds of silence in psychotherapy: The categorization of clients' pauses. Psychotherapy Research, 11(3), 295-309. 
Levitt, H. M. (2001b). Clients' experiences of obstructive silence: Integrating conscious reports and analytic theories. Journal of Contemporary Psychotherapy, 31(4), 221-244.

Levitt, H. M. (2002). The unsaid in the psychotherapy narrative: Voicing the unvoiced. Counselling Psychology Quarterly, 15(4), 333-350.

Lincoln, Y. S. ve Guba, E. G. (1985). Naturalistic inquiry. Beverly Hills, CA: Sage.

Meissner, W. W. (2000). On analytic listening. Psychoanalytic Quarterly, 69(2), 317-367.

Meydan, B. (2015). Bireyle psikolojik danışma uygulamasında Mikro Beceri Süpervizyon Modeli'nin etkililiğinin incelenmesi. Türk Psikolojik Danışma ve Rehberlik Dergisi, 5(43), 55-68.

Miles, M. B. ve Huberman, A. M. (1994). Qualitative data analysis. London: Sage.

Otani, A. (1989). Client resistance in counseling: Its theoretical rationale and taxonomic classification. Journal of Counseling and Development, 67, 458-461.

Patton, M. Q. (2014). Nitel araştırma ve değerlendirme yöntemleri (M. Bütün ve S. B. Demir, Çev. Ed.), Ankara: Pegem Akademi. (Orijinal çalışma basım tarihi 2014.)

Ronningstam, E. (2006). Cultural function and psychological transformation in psychoanalysis and psychoanalytic psychotherapy. The International Journal of Psychoanalysis, 87(5), 1277-1295.

Sabbadini, A. (1986). Possession anxiety: The other side of the castration complex. British Journal of Psychotherapy, 3(1), 5-13.

Sabbadini, A. (1991). Listening to silence. British Journal of Psychotherapy, 7, 406-415.

Shafii, M. (1973). Silence in the service of the ego: Psychoanalytic study of meditation. International Journal of Psychoanalysis, 54, 431-443.

Sharpley, C. F. (1997). The influence of silence upon clinet-perceived rapport. Counselling Psychology Quarterly, 10(3), 237-246. 
Sharpley, C. F., Munro, D. M. ve Elly, M. J. (2005). Silence and rapport during initial interviews. Counselling Psychology Quarterly, 18(2), 149159.

Stringer, J. V., Levitt, H. M., Berman, J. S. ve Mathews, S. S. (2010). A study of silent disengagement and distressing emotion in psychotherapy. Psychotherapy Research, 20(5), 495-510.

Tindall, R. H. ve Robinson, F. P. (1947). The use of silence as a technique in counseling. Journal of Clinical Psychology, 3(2), 136-141.

Urlic, I. (2010). The phenomenon of silence: A group-analytic exploration of meanings in psychotherapy and in everyday life. Group Analysis, 43(3), 337-353.

Weiss, S. (1997). The empty space. J. Winer (Ed.), The annual of psychoanalysis içinde (189-200). Hillsdale, NJ: Analytic Press.

Yaka, B. (2005). Psikolojik danışmanların temel psikolojik danısma becerilerine ilişkin yeterlik düzeylerinin bazı değişkenlere göre incelenmesi. Yayınlanmamış doktora tezi, Ege Üniversitesi Sosyal Bilimler Enstitüsü Enstitüsü.

Yam, F. C. ve İlhan, T. (2016). Psikolojik danışma öz yeterliği: Kişilik özellikleri, kaygı düzeyleri ve geçmiş eğitim yaşantıları. Uluslararası Sosyal Araştırmalar Dergisi, 9(42), 1304-1313.

Yıldırım, A. (1999). Nitel araştırma yöntemlerinin temel özellikleri ve eğitim araştırmalarındaki yeri ve önemi. Eğitim ve Bilim, 23(112), 7-17.

Yıldırım, A. ve Şimşek, H. (2000). Sosyal bilimlerde nitel araştırma yöntemleri. Ankara: Seçkin Yayıncılık.

Yıldırım, T. (2012). Grupla psikolojik danışmada duyamadığımız ses: Suskunluk. Kuram ve Uygulamada Eğitim Bilimleri, 12(1), 119-134. 